\section{Correspondence analysis: a method for classifying similar patterns of violence against women}

\author{
Análise de correspondência: um método para \\ classificação de mulheres com perfil \\ semelhante de vitimização
}

\footnotetext{
${ }^{1}$ Centro de Informação Científica e Tecnológica, Fundação Oswaldo Cruz, Rio de Janeiro, Brasil. ${ }^{2}$ Escola Nacional de Saúde Pública Sergio Arouca, Fundação Oswaldo Cruz, Rio de Janeiro, Brasil.

Correspondence J. C. Mota

Departamento de Informações em Saúde, Centro de Informação Científica e Tecnológica Fundação Oswaldo Cruz. Av. Brasil 4.365, Pavilhão Haity Moussatché, sala 225, Rio de Janeiro, $R J$ 21040-360, Brasil. jmota@cict.fiocruz.br
}

\begin{abstract}
Violence against woman has received relatively little debate in society. It includes physical, psychological, and sexual abuse that jeopardizes the victim's health. Multivariate correspondence analysis and cluster analysis were applied to crimes reported to the Integrated Women's Aid Center in Rio de Janeiro, Brazil, to investigate associations between injury and define criteria for classifying the aggressions. Three groups of abuse were identified, differing according to the nature (physical, psychological, or sexual) and severity of the crimes. Less serious crimes consisted of threats and moderate physical injuries. The intermediate severity group included serious physical assault and threats. More serious crimes included death threats, rape, and sexual assault. The method thus allowed classification of the crimes in three groups according to severity.
\end{abstract}

Violence Against Women; Battered Women; Aggression
Jurema Corrêa da Mota 1

Ana Gloria Godoi Vasconcelos 2

Simone Gonçalves de Assis 2

\section{Introduction}

Violence against women includes a range of physical, psychological, and sexual abuse that degrades the victim's health and self-esteem. The United Nations officially defines violence against women as "any act of gender-based violence that results in, or is likely to result in, physical, sexual, or psychological harm or suffering to women, including threats of such acts, coercion, or arbitrary privations of liberty, whether occurring in public or private life" 1 (p. 3).

Culturally, gender violence is the most well known designation for aggression by men against women. Other names can be used, depending mainly on the relationship between victim and aggressor. For example, domestic violence is conceptually less broad than gender violence and refers to violence by a spouse or other family member against a woman in the household where she lives. Still, the idea of domestic violence is closely associated with spouse violence, since it is usually perpetrated by the intimate partner 2,3 . In this study, domestic violence against women will be defined as violence committed by the male spouse or partner.

The issue of domestic violence against women has still received relatively little debate in society. Frequently characterized as partner aggression, it is generally interpreted as a personal conflict of minor importance. 
According to a survey in Brazil in 2001, one out of five women reported having suffered some type of physical, psychological, or sexual violence, and in most cases the spouse was the main aggressor ${ }^{4}$. A study in 1996 on cases of domestic violence against women treated at emergency services detected a $69.4 \%$ prevalence rate of abuse committed by husbands, partners, or boyfriends 5 .

Legal aid and counseling services can help prevent violence against women and provide an idea of the phenomenon's magnitude in society, despite underreporting. These services, together with research on the issue, foster the elaboration of proposals for preventive action and follow-up for survivors.

The forms of aggression most frequently reported by women are physical, psychological, and sexual abuse ${ }^{6}$. These aggressions cannot be interpreted as mutually exclusive categories, since they frequently occur jointly. For example, in the presence of sexual assault, it is common to identify physical and psychological violence as well, thus characterizing the coexistence of these aggressions 4,7 .

To understand the relationship between bodily injury and abuse, it is useful to evaluate the joint occurrence of these aggressions. This approach to the population treated at the referral center could be useful for identifying groups of women suffering similar patterns of aggression and thus help orient specific measures and responses.

This study used the multiple correspondence technique followed by mixed classification for the crimes reported to a referral center with headquarters in the city of Rio de Janeiro, Brazil, with the aim of exploring simultaneous relations among the different forms of abuse. The analytical tool was applied to identify possible patterns among the aggressions, reflecting important characteristics in this population.

\section{Methodology}

\section{Study population}

This was a descriptive study of 684 women treated at a referral center from January 1999 to December 2000.

The study included women who came to the center after suffering violence perpetrated by the spouse or former spouse, defined according to de facto marital status. We chose to analyze this group with the aim of studying the associations between different forms of violence based on more stable relationships between the victim and the aggressor. This group of women represented $79.2 \%$ of all women treated at the institution for complaints of violence. The sample excluded women whose aggressors were other family members, boyfriends, bosses/employers, workmates, or other individuals, whether known or unknown to the victim.

The study involved the entire sample population according to the above-mentioned inclusion criteria and used information from the institution's treatment forms, which contain socio-demographic characteristics of the victims and aggressors, the crimes committed, and the demands pertaining to each respective situation of violence.

\section{Definition of study variables}

The crimes analyzed here included: threats, death threats, rape, sexual assault, moderate physical injury, and severe physical injury, and more than one crime could be tabulated for each victim. Six crimes were excluded that have low incidence rates and were thus considered outliers: cruel and unusual punishment (6 cases), lewd and lascivious behavior (3), duress (1), sexual harassment (1), racism (1), and murder (1). In the murder case, the victim's mother filed the complaint.

\section{Statistical analysis}

The crimes were submitted to a preliminary multiple correspondence analysis, followed by mixed classification techniques (hierarchical and nonhierarchical partitioning).

Correspondence analysis is an exploratory and descriptive technique to analyze contingency tables with a large number of variables, considering measures of correspondence between rows and columns. This technique can be considered a special case of factor analysis, but it differs to the extent that it evaluates the relationship between categorical data organized in contingency tables, rather than continuous data 8 .

Basically, correspondence analysis converts a non-negative data matrix into a kind of graphic representation that allows studying the relations between the categories of rows and columns in a large contingency table. The technique is appropriate for studying the data structure without hypothesizing an a priori model or assuming a probability distribution, and is thus adequate for studieswith population data, as a non-inferential technique 9 . XLSTAT 4.0 (Addinsoft Company, http:/ / www.xlstat.com/download.htm) and Statistica version 98 (StatSoft Inc., http://www.statsoft. com) were the programs used in the study. 
From this initial matrix, the relationship between the categories of crimes was evaluated based on the distances between the line profiles and marginal probabilities. The resulting distance measure is called distance $\chi^{2}$ and is similar to the common Euclidian distance, from which it differs because it considers the center of gravity in the calculation 8,10 .

To obtain planes that best represent the variables' spatial configuration, one calculates a set of orthogonal axes called eigenvectors 9 . The set of eigenvectors defines the multidimensional space, and one can adopt a minimum number of axes and analyze the points' configuration based on this minimum set of factors 9 . The percentage of variability explained by the method orients the choice of the number of factors to be retained for analysis. The first eigenvector retains the most data variability, while the second eigenvector retains the second most, and so on $8,9,11$.

The importance of the categories of variables for constructing each axis is measured by their absolute contribution and aids the interpretation of the axis. Categories with high absolute contributions show greater importance in the factor's formation. The relative contribution 8 provides information as to how much of the category's variability is explained by the axis.

Graphic analysis of the existence of groups of variables is performed by considering their geometric proximity and the separation of categories by quadrants, because the closer the variables, the more interrelated they are, and those separated by quadrants display groups with opposite profiles 12

A disadvantage of correspondence analysis is that it does not quantify the number of women included in each respectively identified pattern 13. The mixed classification technique produces this type of information in such a way as to complement correspondence analysis. Cluster analysis consists of dividing and grouping a set of $n$ objects into mutually exclusive subsets, so as to guarantee maximum homogeneity within subsets and maximum heterogeneity between them 12 .

For the mixed classification methods, we considered the first three axes, since they had higher eigenvalues than the inverse of the number of active variables 14,15 .

The last stage of the analysis was the description and naming of the classes resulting from the grouping process, which considered the proportions of categories of most significant crimes in each class. To better evaluate this description, the resulting groups and the crimes were resubmitted to multiple correspondence analysis. This last procedure allows corroborating the descrip- tion based on proportions and essentially seeks an understanding of the crimes' behavior in the multidimensional space, according to their geometric proximity to the groups.

\section{Results}

The cumulative percentage of variability explained by each axis, resulting from the correspondence analysis for the first three, was $65 \%$ of the data's total variability.

Table 1 shows the absolute and relative contributions for the first three dimensions. In terms of absolute contributions, the first dimension was formed mainly by death threats (26\%), threats (19.3\%), and rape (16.4\%). The largest contributions to the formation of the second axis were from severe physical injury (33.2\%) and moderate physical injury (13.9\%). For the third factor, the most relevant contribution was from sexual abuse $(41 \%)$, followed by moderate physical injury (11.6\%).

Figures 1 and 2 show the relationships between the crimes and their categories, based on geometric proximity. Figure 1, with only two dimensions, highlights the existence of two groups. One group, whose proximity between the categories included less severe crimes, characterized by the presence of threats, death threats, and moderate injuries and the absence of serious physical injuries, sexual assault, and death threats. A second group, located in the lower left quadrant, consisted of more serious crimes, like rape, sexual assault, and severe physical injury, and is relatively farther removed from the other crimes, indicating that they have different characteristics.

Figure 2, with the additional information from the third axis, corroborates the information from Figure 1 and shows more clearly that sexual abuse was positioned relatively closer to rape and severe physical injury than to moderate injury and threats, in this dimension. The two graphs show that rape and severe physical injury were relatively closer to each other.

The next stage was to group the women according to the configuration of the aggressions identified in the correspondence analysis, using a matrix of coordinates from the women in the first three resulting axes, which were the measures of similarity used in the cluster analysis for classification.

Table 2 shows the results of the mixed classification, with the proportions of variables and their categories for each group as a whole. The hierarchical classification revealed the best grouping in four partitions. Due to the difficulty in specify- 
Table 1

Percentage of categories of crimes, and absolute and relative contributions to violence against women. Integrated Women's Aid Center, Rio de Janeiro, Brazil, 1999 and 2000.

\begin{tabular}{|c|c|c|c|c|c|c|c|c|}
\hline \multirow[t]{2}{*}{ Crimes } & \multirow[t]{2}{*}{ Categories } & \multirow{2}{*}{$\begin{array}{l}\text { Proportion } \\
\text { of women }\end{array}$} & \multicolumn{3}{|c|}{ Absolute contribution } & \multicolumn{3}{|c|}{ Relative contribution } \\
\hline & & & Axis 1 & Axis 2 & Axis 3 & Axis 1 & Axis 2 & Axis 3 \\
\hline \multirow[t]{2}{*}{ Rape } & Absent & 98.0 & 0.32 & 0.17 & 0.18 & 0.26 & 0.12 & 0.10 \\
\hline & Present & 1.90 & 16.41 & 8.88 & 9.12 & 0.26 & 0.12 & 0.10 \\
\hline \multirow[t]{2}{*}{ Death threats } & Absent & 65.3 & 13.81 & 1.26 & 5.78 & 0.61 & 0.05 & 0.17 \\
\hline & Present & 34.6 & 26.05 & 2.37 & 10.89 & 0.61 & 0.05 & 0.17 \\
\hline \multirow[t]{2}{*}{ Moderate injuries } & Absent & 41.5 & 1.87 & 19.59 & 16.43 & 0.05 & 0.45 & 0.29 \\
\hline & Present & 58.4 & 1.33 & 13.91 & 11.67 & 0.05 & 0.45 & 0.29 \\
\hline \multirow[t]{2}{*}{ Severe injuries } & Absent & 93.7 & 0.16 & 2.23 & 0.13 & 0.04 & 0.48 & 0.02 \\
\hline & Present & 6.28 & 2.32 & 33.20 & 1.97 & 0.04 & 0.48 & 0.02 \\
\hline \multirow[t]{2}{*}{ Threats } & Absent & 60.38 & 12.70 & 6.61 & 0.29 & 0.49 & 0.23 & 0.01 \\
\hline & Present & 39.6 & 19.35 & 10.07 & 0.44 & 0.49 & 0.23 & 0.01 \\
\hline \multirow[t]{2}{*}{ Sexual abuse } & Absent & 95.3 & 0.27 & 0.08 & 2.02 & 0.09 & 0.02 & 0.45 \\
\hline & Present & 4.67 & 5.43 & 1.63 & 41.09 & 0.09 & 0.02 & 0.45 \\
\hline
\end{tabular}

ing the four group's most distinct characteristics and in order to avoid repetitive descriptions, we selected a three-class partitioning. Description of the groups only considered the presence of the categories of variables.

Group 1 was best characterized by moderate physical injury (97.4\%) as compared to groups 2 and 3 . Threats also had a significant weight in this class. Importantly, it did not include rape and severe physical injury. Thus, based on this group's characteristics, it can be termed moderate physical and psychological harm.

Group 2 placed the greatest weight on death threats (99.5\%). Rape was the second most characteristic crime in this class $(5.6 \%)$. There was little or no rape in groups $1(0.6 \%)$ or $3(0 \%)$, so that rape, together with death threats, can be considered the crimes that characterized group 2, which can be termed severe sexual harm.

Group 3 included, as compared to groups 1 and 2 , threats (88.3\%) and severe physical injuries, and could thus be termed severe physical and psychological harm. Severe physical injuries were absent from group $1(0 \%)$ and infrequent in group 2 (3.8\%). This class included virtually no sexual crimes.

The three groups differed due to the presence of different categories of injuries, threats, and sexual crimes, and not only based on the nature of the crime (physical, psychological, or sexual). Groups 1 and 3 (moderate versus severe physical and psychological harm, respectively) differ from each other based on the types of injuries that most represent them. The moderate physical and psychological harm group included moderate physical injuries, while the severe physical and psychological harm group included severe physical injuries. Threats were the second most relevant type of aggression in these two groups, although the frequency was higher in the severe physical and psychological harm group. The severe sexual abuse group differed from the others because it was the only one in which death threats had a more relevant weight, followed by rape, which was only present in this group.

These classes appear to indicate levels of severity in relation to categories of crimes perpetrated. Severe sexual violence constituted the most serious grouping, with the presence of death threats and rape (crimes of a psychological and sexual nature). The severe physical and psychological harm group can be a considered a second serious class, due to the presence of severe physical injuries, and the moderate physical and psychological harm group can be considered a class characterized by relatively less serious violence, since its main characteristic was the presence of moderate physical injuries.

Figure 3 shows the results of the multiple correspondence analysis, including the groups and categories of crimes as active variables. The first two planes, retained for description, represent $59.4 \%$ of the data variability.

The figure corroborates the findings from the description of the groups, based on the proportions of each crime category. The moderate phys- 
Categories of crimes in the first two dimensions of the multiple correspondence analysis. Integrated Women's Aid Center, Rio de Janeiro, Brazil, 1999 and 2000.

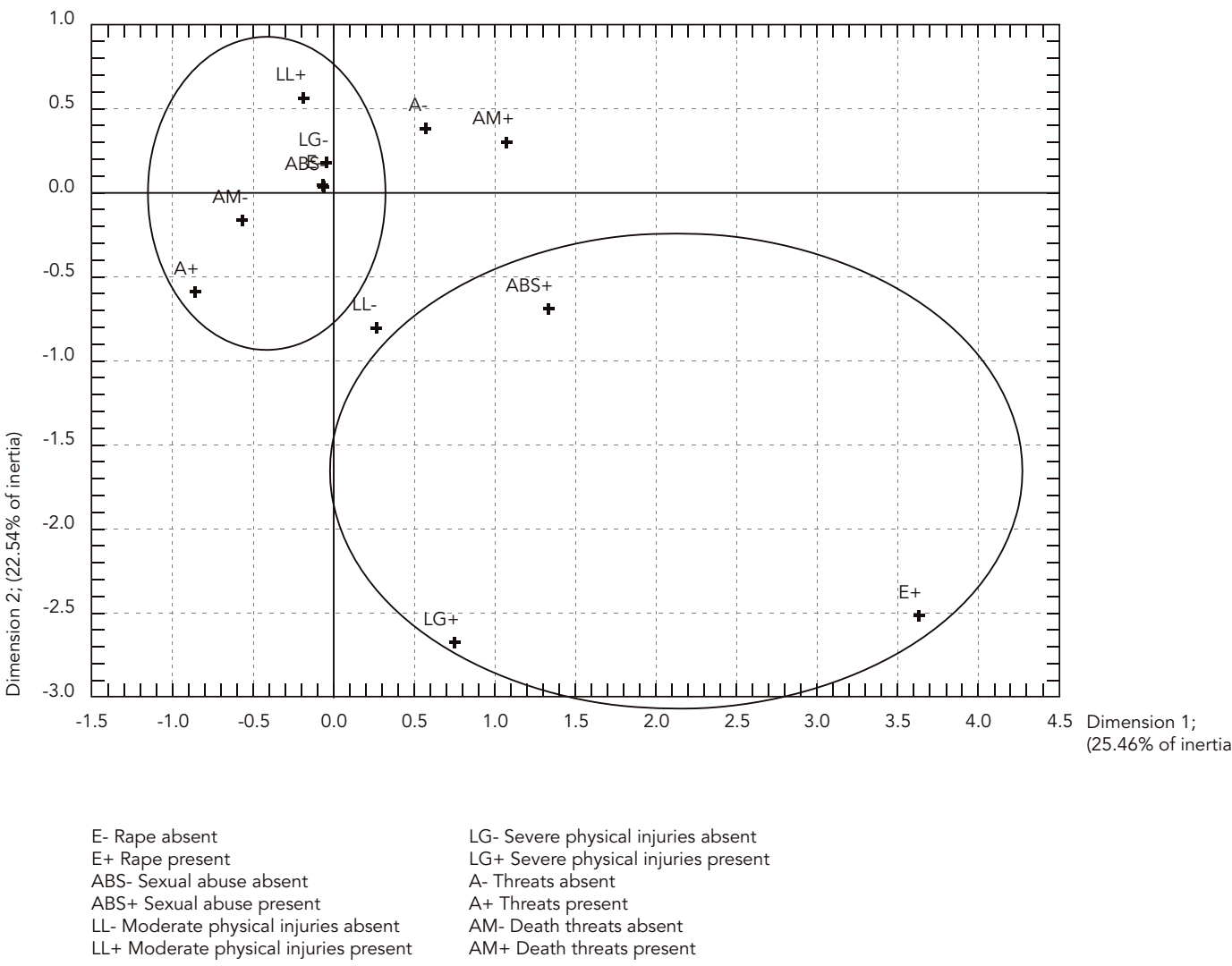

ical and psychological harm group is positioned relatively closer to moderate physical injuries, the crime that best characterizes the group. The severe sexual violence group, considered the most serious of all the respective classes, bears a strong relationship to death threats and rape. The severe physical and psychological harm group, with intermediate severity in relation to the other two groups, is most closely related to the presence of severe physical injuries, the crime that best characterizes the group.

Some crimes were located in intermediate positions between the groups. In the analysis of proportions in Table 2, these were the aggressions that did not show clearly outstanding values in relation to a specific group. This was the case for sexual violence, with similar proportions between the groups classified as moderate physical and psychological harm and severe sexual violence, with an equidistant position in Figure 3 in relation to these two categories. Threats were positioned between the groups of moderate and serious physical and psychological harm. The proportions of threats in the groups showed a stronger relationship to severe physical and psychological harm, as demonstrated by the shorter distance between this aggression and this group, in addition to belonging to the same quadrant.

\section{Discussion}

Multiple correspondence analysis and subsequent cluster analysis have proven to be an important tool for classifying aggression, although they have been used little in Brazil in studies on violence against women and violence in general. Application of this technique allowed classify- 


\section{Figure 2}

Categories of crimes in the first three dimensions of the multiple correspondence analysis. Integrated Women's Aid Center, Rio de Janeiro, Brazil, 1999 and 2000.

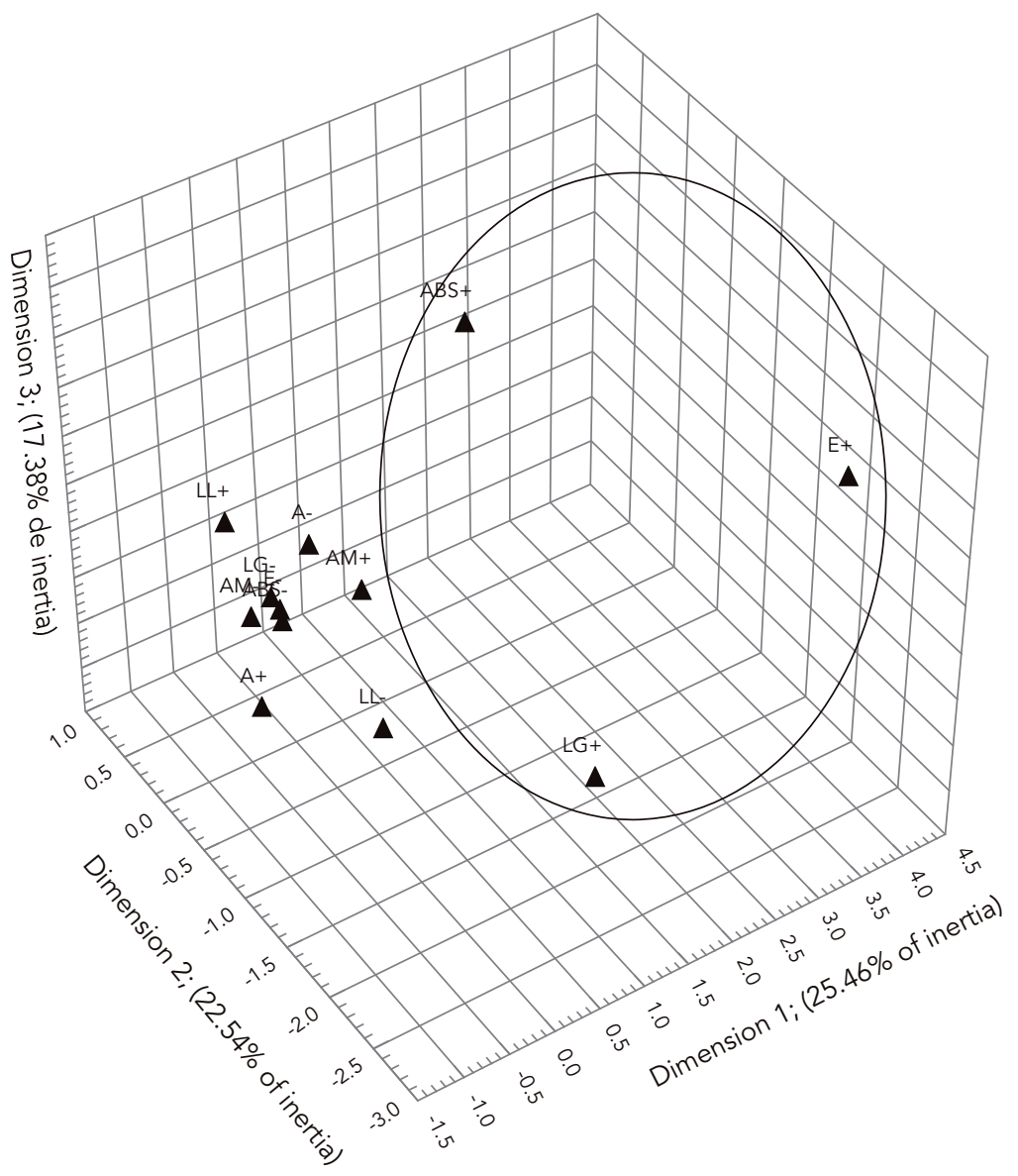

E- Rape absent

E+ Rape present

ABS- Sexual abuse absent

ABS + Sexual abuse present

LL- Moderate physical injuries absent

$\mathrm{LL}+$ Moderate physical injuries present
LG- Severe physical injuries absent $L G+$ Severe physical injuries present A- Threats absent A+ Threats present AM- Death threats absent $\mathrm{AM}+$ Death threats present ing the crimes in three classes which, based on theoretical knowledge of these aggressions, can be ordered according to their relative degree of severity.

The moderate physical and psychological harm group was taken to be the least serious category, whose typical crimes were moderate physical injuries and threats. These types of aggressions are usually the most common crimes involved in violence against women. Physical injury is considered moderate if the victim is forced to be absent from her normal occupations for less than 30 days. If this period extends beyond 30 days, the crime is characterized as severe physical injury.

Any such injuries, whether moderate or severe, always involve offense to the victim's physical integrity. In the case of severe injuries, in which the victim is absent from her normal activities for more than 30 days, the crime is more serious, explaining why the severe physical and psychological harm group was considered more serious than the moderate physical and psychological harm group. Since threats were more heavily associated with this crime, this aggression is psychologically more complex and serious.

The hypothesis is that threats range from more subtle verbal abuse to more serious situations. Threats, present in the severe physical and psychological harm group in association with severe physical injury, characterize a type that does not reach the level of death threats, but are not possibly similar to threats associated with moderate physical injury in the group involving moderate physical and psychological harm.

Although the crimes were recorded not on the basis of the victims discourse, but on the Complaint Forms, i.e., with proof of the aggression based on a forensic medical examination of the victim, in terms of harm to women's mental health, it is often difficult to clearly distinguish between the concepts of moderate and severe abuse. A crime classified as "moderate" based on the result of a forensic medical examination may well have "severe" subjective consequences for the victim. This study's quantitative approach does not capture the meaning of the crimes for the victims. The classification obtained here can be complemented with qualitative research to grasp the meaning of crimes for survivors and may or may not lead to a different classification.

According to a Brazilian study 16 on the operational conditions of 267 Special Women's Precincts, the most frequent complaints in 1999 referred to physical injuries (36.8\%), followed by (33\%). Crimes involving affray, in which the victim reacts in kind to the violence, were the third most frequent (9.8\%). Rape complaints constituted $1.4 \%$ of the total. In the State of Paraná, $7.6 \%$ of all cases of sexual assault in 1998 were perpetrated by intimate partners 17 .

The case breakdown in the current study involved $58.4 \%$ moderate physical injuries, $39.6 \%$ threats, $34.6 \%$ death threats, and $1.9 \%$ rape. The different prevalence rates for various crimes in the previously quoted studies as compared to the Integrated Women's Aid Center can be explained mainly by the fact that they analyzed different 
Categories of crimes and resulting classification groups in the first two dimensions. Integrated Women's Aid Center, Rio de Janeiro, Brazil, 1999 and 2000

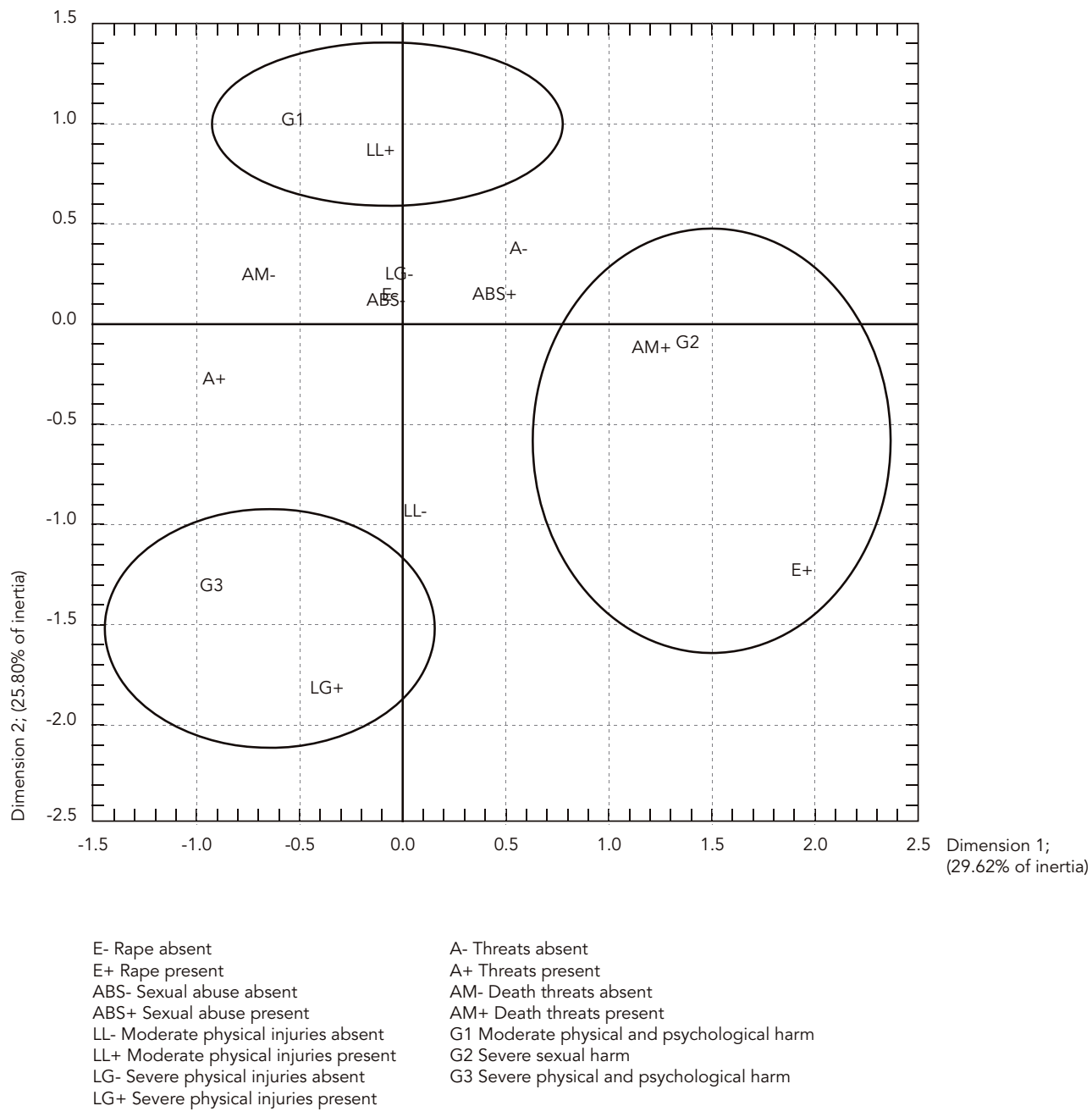

target populations. The women analyzed in the current study constitute a more specific population group, victims of intimate partners violence, thus making it a more homogeneous group. The complaints filed at the Women's Precincts included a broader range of crimes, perpetrated by different types of aggressors, including not only intimate partners but also other family members and even strangers, even though most of the complaints involved spouse violence.

Severe sexual violence was considered the most serious group, with a strong presence of death threats and rape. Rape and various forms of lewd and lascivious behavior are modalities of sexual aggression that use force, coercion, and serious threats, and the resulting physical injuries and psychological trauma can vary in severity ${ }^{18}$. Physical violence is not always present in rape cases, and is not a mandatory component under Brazil's Criminal Code, while psychological violence is always present and leaves deep emotional scars 18 . The current study's findings corroborate this, since both moderate and severe injuries occurred with significant weights in the group that included threats and rape.

Sexual abuse did not show a different weight in the various groups. Its frequency was virtually similar in the group involving moderate physi- 
Proportion of categories of crimes present and absent in groups resulting from multiple correspondence analysis followed by mixed classification. Integrated Women's Aid Center, Rio de Janeiro, Brazil, 1999 and 2000.

\begin{tabular}{lcccc}
\hline Crimes & Categories & $\begin{array}{c}\text { Moderate physical } \\
\text { and psychological } \\
\text { (Group 1) * }\end{array}$ & $\begin{array}{c}\text { Severe sexual } \\
\text { violence } \\
\text { (Group 2) ** }\end{array}$ & $\begin{array}{c}\text { Severe physical } \\
\text { and psychological } \\
\text { harm (Group 3) *** }\end{array}$ \\
\hline Rape & Absent & 100.0 & 94.4 & 99.4 \\
Present & 0.0 & 5.6 & 0.6 & \\
Death threats & Absent & 96.1 & 0.5 & 92.0 \\
Present & 3.9 & 99.5 & 8.0 & 96.9 \\
Moderate physical injuries & Absent & 2.6 & 55.4 & 78.5 \\
Present & 97.4 & 44.6 & 3.1 & \\
Severe physical injuries & Absent & 100.0 & 96.2 & 11.7 \\
Present & 0.0 & 3.8 & 21.5 & \\
Threats & Absent & 58.8 & 100.0 & 98.2 \\
Present & 41.2 & 0.0 & 88.3 & \\
Sexual abuse & Absent & 94.5 & 94.4 & \\
Present & 5.5 & 5.6 & 1.8 & \\
\hline
\end{tabular}

${ }^{*} \mathrm{~N}=308(45.0 \%) ;$

** $N=213(31.1 \%) ;$

$\star \star \star * N=163(23.8 \%)$

cal and psychological harm and severe sexual violence, which due to the presence of rape and death threats, potentially causes greater physical and emotional harm to the victim. The different manifestations of sexual abuse include variations that are often difficult to categorize, ranging from seduction to lewd and lascivious behavior, without necessarily producing visible marks on the victim 17 . Sexual abuse can thus range from more subtle forms to crimes involving more severe consequences.

The findings for sexual abuse patterns are consistent with the literature on sexual violence. Sexual abuse can be classified in three levels: without physical contact, with physical contact, and with violent physical contact, and its manifestation without physical contact includes verbal offenses in the form of obscene telephone calls, exposing of genitals, and others, while the forms with physical contact include fondling, masturbation, fellatio, and anal and vaginal coitus 18. Sexual assault with violent physical contact includes violence, harm, physical injury, and serious threats of physical injury 19.

One of this study's limitations was that it was unable to analyze how often the same woman suffered a given aggression or evaluate the context of the aggression, like kicking, using sharp objects, and imposing prohibitions, since such information is not included on the complaint forms. The frequency and context of the abuse are relevant and should be considered in studies on violence against women. The inclusion of such characteristics could result in a different classification from the one found in this study. Since the classification is specific to the given population sample and the crimes analyzed, and also considering the properties of the statistical technique used here, another limitation is that the current study does not allow extrapolation of the results to the overall population of female victims of violence.

This was an exploratory study to classify abuse against women, premised on the natural existence of groups in the data structure. Even with this peculiarity, the method can be considered an alternative for the analysis of interrelations between injuries, even for more specific population groups, and can be used for other studies on health and violence.

The proposed methodology for classifying the crimes can be used for the issue of violence, since knowledge of the interrelations between types of aggression has been underutilized to date and could help the respective social and health services to provide better referrals for victims. Correspondence analysis is an appropriate technique for analyzing categorical data, generally the ones used in these services, also subsequently applied to studying relations between the socio-demo- 
graphic characteristics of victims and aggressors and groups of violence, whereby one can distinguish the profile of female victims of partners as to severity of the violence 20 .

The three groups of violence obtained in this study differed not only as to the nature of the physical, psychological, and sexual crime, but also in the severity of abuse. This classification not only provides specific knowledge on the re- ported crimes, but also indicates that the severity and nature of the aggressions should be considered when proposing a classification of violence. The analysis of these interrelations can shed new light for services that assist women in situations of violence, suggesting other forms of classification of violence and organization of care, according to the reality of the women who turn to them for help.

\section{Resumo}

A violência contra a mulher é uma questão ainda pouco debatida na sociedade, abrangendo um conjunto de agressões físicas, psicológicas e sexuais que contribuem para a depreciação da saúde da vítima. Aplicou-se a técnica de análise de correspondência multivariada seguida da técnica de análise de cluster aos crimes registrados no Centro Integrado de Atendimento à Mulher, Rio de Janeiro, Brasil, com o objetivo de investigar o padrão de associação entre os agravos e estabelecer critérios para a classificação das agressões. Identificaram-se três grupos que se distinguem pela natureza do crime (físico, psicológico e sexual) e pelos níveis de gravidade. O menos grave é formado pelos crimes de lesão corporal leve e ameaça. O de gravidade intermediária reúne crimes de lesão corporal grave e ameaça. No de maior gravidade estão os crimes de ameaça de morte, estupro e abuso sexual. O método permitiu a classificação dos crimes em três grupos, que podem ser ordenados de acordo com o grau de severidade que guardam entre si.

Violência Contra a Mulher; Mulheres Maltratadas; Agressão

\section{Contributors}

J. C. Mota participated in the data collection and analysis and drafting of the article. A. G. G. Vasconcelos and S. G. Assis participated in the data analysis and drafting of the paper. 


\section{References}

1. World Health Organization. Dando prioridad a las mujeres: recomendaciones éticas y de seguridad para la investigación sobre la violencia doméstica contra las mujeres. Geneva: World Health Organizations; 2001.

2. Day VP, Telles LEB, Zoratto PH, Azambuja MRF, Machado DA, Silveira MB, et al. Violência doméstica e suas manifestações. Rev Psiquiatr Rio Gd Sul 2003; 25:9-21.

3. World Health Organization. World Report on Violence and Health. Geneva: World Health Organization; 2002.

4. Fundação Perseu Abramo. A Mulher brasileira nos espaços público e privado - como vivem e o que pensam as mulheres no século XXI. http://www. fpa.org.br/nop/mulheres/violencia.htm (accessed on $17 / \mathrm{Feb} / 2004)$.

5. Deslandes SF, Gomes R, Da Silva CMFP. Caracterização dos casos de violência doméstica contra a mulher atendidos em dois hospitais públicos do Rio de Janeiro. Cad Saúde Pública 2000; 16:129-37.

6. Heise L. Gender Based Abuse: the global epidemic. Cad Saúde Pública 1994; 10 Suppl 1:135-45.

7. Schraiber LB, D’Oliveira AFPL, França-Junior I, Pinho AA. Violência contra a mulher: estudo em uma unidade de atenção primária à saúde. Rev Saúde Pública 2002; 36:470-7.

8. Clausen SE. Applied correspondence analysis: an introduction. Quantitative applications in the social sciences. Thousand Oaks: Sage University Papers Series; 1998.

9. Greenacre MJ. Practical correspondence analysis. In: Casella G, Fienberg S, Olkin J, editors. Looking at multivariate data. New York: John Wiley and Sons; 1981. p. 119-46.

10. Pereira JCR. Análise de Dados Qualitativos: estratégias metodológicas para as ciências da saúde, humanas e sociais. São Paulo: Editora da Universidade de São Paulo; 1999.

11. Lebart L, Morineau A, Warwick KM. Multivariate descriptive statistical analysis: correspondence analysis and related techniques for large matrices. New York: John Wiley and Sons; 1984.
12. Aranha RN, Faerstein E, Azevedo GM, Werneck G, Lopes CS. Análise de correspondência para avaliação do perfil de mulheres na pós-menopausa e o uso da terapia de reposição hormonal. Cad. Saúde Pública 2004; 20:100-8.

13. Laflamme L, Backström T, Döös M. Typical accidents encountered by assembly workers: six scenarios for safety planning identified using multivariate methods. Accid Anal And Prev 1993; 25:399-410.

14. Morineau A. Note sur la caracterisation statistique d'une classe et les valeurs-Testes. Bulletin Techique CESIA 1984; 2:20-7.

15. Carvalho MS, Struchiner CJ. Análise de correspondência: uma aplicação do método à avaliação de serviços de vacinação. Cad Saúde Pública 1992; 8:287-301.

16. Silva KC. As DEAMs, as corporações policiais e a violência contra mulheres: representações, dilemas e desafios. http://www.mj.gov.br/sedh/cndm (accessed on 01/Feb/2003).

17. Rede Nacional Feminista de Saúde e Direitos Reprodutivos. Violência contra a mulher. http:// www.cefemea.org.br (accessed on 20/Dec/2003).

18. Priante PSB. Perfil da Violência Sexual Contra Mulheres no Município de Belém do Pará [Dissertação de Mestrado]. São Paulo: Universidade Federal de São Paulo; 2000.

19. Sanchez-Martinez F, Hernandez SE, Veras CM, Payán JEC, Nuñez AM. Abuso sexual en el municipio de La Veja, provincia de La Vega. Act Med Dom 1994; 16:82-5.

20. Mota JC, Vasconcelos AGG, Assis SG. Análise de correspondência como estratégia para descrição do perfil da mulher vítima do parceiro atendida em serviço especializado. Ciênc Saúde Coletiva 2007; 12:799-809.

Submitted on 22/Dec/2006

Final version resubmitted on $11 /$ Sept/2007

Approved on 10/Oct/2007 